\title{
Ssciendo
}

Ethics \& Bioethics (in Central Europe), 2021, 11 (3-4), 206-216

DOI:10.2478/ebce-2021-0011

\section{Intercultural dialogues in times of global pandemics: The Confucian ethics of relations and social organization in Sinic societies}

\author{
Jana S. Rošker ${ }^{1}$
}

\begin{abstract}
Since COVID-19 is a global-scale pandemic, it can only be solved on the global level. In this context, intercultural dialogues are of utmost importance. Indeed, different models of traditional ethics might be of assistance in constructing a new, global ethics that could help us confront the present predicament and prepare for other possible global crises that might await us in the future. The explosive, pandemic spread of COVID-19 in 2020 clearly demonstrated that in general, one of the most effective tools for containment of the epidemics is precisely human and interpersonal solidarity, which must also be accompanied by a certain degree of autonomous self-discipline. The present paper follows the presumption that these types of personal and interpersonal attitudes are-inter aliaculturally conditioned and hence influenced by different traditional models of social ethics. In light of the fact that East-Asian or Sinic societies were more successful and effective in the process of containing and eliminating the virus compared to the strategies of the Euro-American regions, I will first question the widespread assumption that this effectiveness is linked to the authoritarian political traditions of the Sinic East and Southeast Asian areas. Then, I will critically introduce the Confucian ethics of relations, which in various ways has influenced the social structures of these regions, and clarify the question of whether and in which way the relics of this ethics had an actual effect on the crisis resolution measurements. The crucial aim of this paper is to contribute to the construction of theoretical groundworks for a new, transculturally grounded global ethics, which is more needed today than ever before.
\end{abstract}

Keywords: global pandemic, COVID-19, intercultural exchanges, Confucianism, structure of Sinic societies

\section{Introduction}

In this paper I will address the problems of global pandemic situations through the lens of transcultural studies. The primary motive for writing this study was to gain general insight into the various culturally conditioned practices that were observed during the COVID-19 crisis and to acquire common knowledge about the cultural backgrounds of various methods, procedures, and measures that were used to deal with the crisis.

As a sinologist working on Chinese intellectual history, I will focus in this context on the Chinese experience and in particular, as the title of this paper suggests, on Confucian philosophy and ethics. In this regard, I will mainly deal with the so-called Sinic region. This is a cultural and linguistic area that overlaps geographically with most East-Asian regions, as well as certain regions in Southeast Asia, such as, for instance, Vietnam and partly even Singapore. The term applies to all areas that have traditionally used Chinese writing and were historically strongly influenced by certain elements of Chinese culture, particularly by Confucianism, but also by Chan Buddhism and some other ideational systems that originated in China. ${ }^{2}$

My primary motivation to investigate the problem of premodern and traditional ethical models in the Sinic region dates back to the year 2020, to the time of the initial spread of the COVID-19 pandemic. As a Sinologist I cannot let go of the fact that the novel coronavirus, which leads to a respiratory illness with a high rate of contagiousness and mortality, first appeared in China, and thus in the cultural and linguistic area that comprises the core of my personal and professional interests, and therefore the fundamental focus of my academic work. But already in spring 2020, as the pandemic progressed, it also quickly became clear that Sinic societies (including China) were much more efficient at containing its spread than societies in the geopolitical realms of Europe and the United States.

\footnotetext{
${ }^{1}$ University of Ljubljana (Slovenia); ORCID: 0000-0003-0072-1556

${ }^{2}$ For the example of Korea, see for instance Maldonado (2020, pp. 129-130).
} 
Many authors attributed the social reasons behind the high level of cooperation required for this to the populace's general sense of obedience and collectivism (Escobar, 2020b, p. 3), which is supposedly related to the autocratic organization of traditional Sinic societies and is part of the common political thought tradition of East Asian societies based on Confucianism. However, such a position is superficial and generalizing, especially considering that the most effective measures against the spread of coronavirus were taken in those East Asian countries that are not autocratic but have a democratic social order, such as Taiwan or South Korea. In order to refute such superficial and unfounded assumptions, which are not only based on popular prejudices but also feed and reinforce them, we will first take a closer (and more substantiated) look at the thesis of alleged Asian authoritarianism. Then, I will proceed from the presumption that the reasons for this efficiency are rather connected to patterns of interpersonal behavior that originated in traditional and classical Sinic ethics, and particularly in Confucian moral philosophy. In the following, I will critically introduce the main paradigms of classical and traditional Confucian ethics, which is a type of deontological ethics, founded on the importance of interpersonal relations. On this basis, I will illuminate some crucial problems regarding the theoretical groundworks of a possible transcultural global ethics, ${ }^{3}$ which might help us solve the present and possible future crises of our common world.

\section{The thesis of immanent authoritarianism}

Let us first examine the background and underpinnings of widespread claims, according to which the reasons for the Sinic efficiency in containing the spread of the coronavirus were linked to the "Confucian autocratic traditions", which allegedly historically prevailed in the region (see for instance Han, 2020a, p. 4; Oviedo, 2020, p. 4; Escobar, 2020a, p. 2). In the next part of this section, I will show why such claims proceed from a latently Eurocentric and Orientalist position.

Some scholars, like the contemporary Berlin-based philosopher of Korean descent ByungChul Han, see the reasons for the faster establishment of measures to stop the spread of the pandemic in East Asia in the region's autocratic traditions. Han writes:

What advantages in the fight against the pandemic, compared to Europe, can we find in the Asian system? Asian countries like Japan, Korea, China, Hong Kong, Taiwan and Singapore have an authoritarian mindset, originating from their cultural tradition (Confucianism). People are less rebellious and more obedient than in Europe (Han, 2020, p. 2).

As indicated above, such claims are populist, generalising, and lacking in scientifically verifiable evidence. To begin with, the thesis of the alleged "all-around obedience" of people throughout the Sinic region, as compared to Europe and America, where people are supposed to be more critical and less compliant (as the above statement implicitly implies), is completely unfounded. Instead, it is based on the widespread assumption that Confucianism is a conservative normative ethic that advocates gerontocracy and the suppression of the individual for the good of the state. Few of the people who blindly advocate such theses actually have any real knowledge of the subject under discussion, and even fewer of them are aware that the ethics

\footnotetext{
${ }^{3}$ Transcultural global ethics cannot be confused with universal ethics, even though the system is based on certain general premises that are common for all humanity. It is a dynamic and continuously changing unity of ideas, standards, and values, composed of different ethical paradigms and normative regulations, which originate in various cultures. Such an ethical system should answer the topical requirements of the current globalized world in a process of transcultural sublation, that is, a process that transcends the orthodox static formulation of culture and thus opens up the possibilities for the formation of new, transculturally conditioned horizons that enable us to theorize contents that originally belonged to separate systems or categories.
} 
of the original Confucianism were extremely progressive and critical of the social attitudes of the time for the era in which it arose.

The ethical system of original Confucianism is based on the premise of humaneness (ren), which is a kind of reciprocal empathy, and defined by placing a high value on the type of education that raises the younger generations into respectable and learned, but also critical and autonomous adults. The Confucian Analects are teeming with segments that undoubtedly argue for the type of education, such as: "Learning without thought is empty; thought without learning is perilous" (Lunyu, s.d., Wei zheng, 15).

A similar spirit springs from Confucian commentaries on Confucius's classic The Spring and Autumn Annals, which often advocate critical and autonomous decision-making:

If the ruler says something is right, then everyone says it is right. And if he claims something is wrong, then everyone will claim the same thing. But that's like watering down an already watery soup with more water-who would want to eat it? Or as if the instruments in an orchestra all played the same musical line-who would want to hear it? Such sameness is not good (Chunqiu Zuo zhuan, s.d., Shao Gong ershi nian, 2).

Even Xunzi, one of Confucius's most famous successors, who was otherwise known as an advocate for a "harder" version of the pragmatic-rational Confucianism, unequivocally points out that the people have the right to dethrone an unsuitable, immoral, and despotic ruler: "The ruler is like a boat, the people are like water. The water can carry the boat, but can also overturn it" (Xunzi, s.d., Wang zhi, 5).

Original Confucian teaching were quite progressive for their time and they doubtless included many proto-democratic elements; in this regard, we should mention the idea of "people as the root" (Min ben) which represented a crucial foundation of Confucian political philosophy.

On the other hand, during the time of East Asian modernization, Confucianism was seen as a dogma that had outlived its usefulness, one that oppressed individuals and did not tolerate their free and autonomous choices. Such a Confucianism was of course seen as the complete opposite to the kind of modernization that was being "imported" from the West, and whose foundational premises were defined based on autonomy and the freedom of the individual subject, as well as their critical and innovative thinking and action. During the period of East Asian "Enlightenment," Confucianism was seen as a reactionary enemy of all forward-looking people who were trying to lead East Asia on a path towards the formation of modern societies based on equality and democracy. It is of course true that the Confucianist system was, in the Sinic societies of this pre-modern era, most widespread in the form of a dogmatic normative ethics, drenched in gerontocracy and advocating scholastic models of education for the young, who were supposed to - exclusively through rote memorization - uncritically adopt the dogmas of the ruling elites. As such, this form of Confucianism also oppressed young people, women, and marginalized social groups.

Here it is important to consider the difference between Confucian philosophy and its ethical discourses (Ru xue) on the one hand, and Confucian state doctrine or dogmatic normative ethics $(R u$ jiao $)$ on the other. As mentioned earlier, Confucianism in the pre-Qin period was a progressive ethics that sharply criticized the concept of hereditary monarchy and advocated instead a proto-republican system in which the ruler would be elected primarily on the basis of his wisdom and moral maturity. This meritocratic system was based on the cultivation of one's personality and the discovery of the autonomous moral self within one's own mind. Its ideational foundation was based on the concepts of the aforementioned empathic humaneness (ren), and situational righteousness or appropriateness ( $y i$ ). At the same time, this was an ethics based on diversity. The harmony for which the original Confucians stood was the harmony of pluralism, not an equalizing alignment of all individuals within a society (Sernelj, 2020, p. 169). Of course, this diversity also meant that society was structurally ordered according to the 
Confucian design, which involved a normative arrangement of relationships or roles for individuals in a society.

Although in institutionalized official Confucian state discourse, the prevailing view is that society is strictly hierarchically ordered, this is not at all true in original Confucian philosophy. In this context, let us examine the Confucian theory of the "five relations" (wu lun) in more detail. Indeed, the political theory of original Confucianism was based on these five relations, which originate in the family and have a paradigmatic character for all relationships within the broader community, including the state. Confucius' successor Mencius defined these relationships as follows:

Father and son should love one another and the relationship between the ruler and their subject should be defined by appropriateness. Between husband and wife there should be difference. Between old and young, there should be a proper order, and between friends, trustworthiness (Mengzi, s.d., Teng Wen Gong I, 4).

Hierarchy in the sense of prioritizing the decisions of a superior can only be seen in the relationship between a ruler and a subject, and between members of the older and younger generations. In the first case, the nature of the relationship itself is hierarchical, meaning that the ruler is naturally his subjects' superior. But, especially in Confucianism, this does not necessarily mean that the latter must be absolutely obedient to the former; on the contrary, the Confucian definition of this relationship requires the ruler to be proper and responsible to his subjects. In fact, the real authority, in the sense of hierarchical primacy, is present in the relationship between members of the older and younger generations, such a relationship being defined by the requirement of proper order $(x u)$ based on the sequence or order of priorities in decision-making. Here we have the only type of relationship within the framework of Confucian relational ethics in which one of the two opposing poles has absolute authority and priority in decision-making, although even in this case the older generation shares responsibility for the younger's welfare. On the other hand, this is undoubtedly an element from which gerontocracy later emerged as one of the most problematic elements of Sinic social systems; however, we must also not overlook the fact that even this view was quite progressive for the time in which Confucian teachings emerged; we must not forget that in a semi-agrarian society of that time, the practices of killing and neglecting the elderly still existed.

With regard to the context of this paper, this element of Confucianism is especially interesting in light of the fact that the elderly comprise over $90 \%$ of the victims of the COVID19 pandemic, and even more so in light of the utilitarian calculations that were applied in some states facing a lack of medical equipment, and that were supposed to make it possible to define which human lives were worth saving at the cost of others that could be sacrificed. However, as we are going to deal with these issues in later chapters, I will for now return to the central question of the present chapter and focus on the problem of autocratic elements in Confucian political and ethical discourses.

During the period of the first unification of China under the auspices of the Qin Dynasty (221 BCE), Confucianism was, like most other intellectual currents of the pre-Qin period, banned. The only permitted thought in this totalitarian, but luckily short-lived dynasty, was the ideology of Legalism ( $f a$ jia ), a Machiavellian political doctrine that served the interests of the absolute ruler and was based on repressive legislation and control over individuals and all social groups.

It was only after the defeat of the Qin under the rule of the new Han Dynasty (206 BCE-220 $\mathrm{CE})$ that the classical schools of philosophy were rehabilitated. And during the Han Dynasty period, a new state doctrine was also established. The court ideologue Dong Zhongshu used Confucianism as the basis of this new system of ideas, and at the same time managed to covertly incorporate a number of repressive and despotic Legalist elements into it. Thus, a new autocratic 
state doctrine was formed from the originally democratic Confucianism. The Legalist elements of totalitarianism and oppression of the state over the individual are latently present in China to this day. Such Legalistic elements, which were thus seen as integral parts of Confucianism, include, for example, procedures such as the method of collective responsibility or the principle of denunciation.

If we try in a very short (and somewhat generalizing) way to review the basic differences between Confucianist doctrine and Confucian philosophy, we can say that the former represented an institutionalized form of state policy, while the latter represented a school of thought or a deontological ethics based on individual autonomy.

Confucianism received its institutionalized basis as a state doctrine primarily with the introduction of civil service examinations, which thereafter formed the intellectual basis of civil service until their abolition in 1905. The material that had to be learned in order to attain an official position (and thus political power) consisted mostly of the Confucian classics. The system of examinations, however, was completely at odds with the basic principles of Confucianism, as it required candidates to simply memorize the material (without the contemplation desired by Confucius), along with internalizing the formal rules of writing reports and essays. The clearest difference between Confucianist doctrine and Confucian philosophy, however, is the fact that state doctrine also included (explicitly unnamed) Legalist methods of control and oppression. Through such use (or rather misuse) of the original Confucian ethics, the five paradigmatic relationships then actually developed a hierarchical character. This was expressed not only within the state's bureaucratic institutions, but also in the strict normative social ethics that formed and spread among the people based on this new doctrine. This Confucianist doctrine-both in its institutional and popular forms - actually posed an obstacle to East Asia's modernization through its dogmatism and conservatism, although different regions solved this problem in different ways. Also, the majority of today's repressive measures as applied by the various authoritarian states in the Sinic, i.e. traditionally Confucian, regions, are still based on Legalist elements within Confucianism. This applies to arranged marriages, which are still widespread - especially in rural areas - as well as to the modern digitalized "social credit system," which was introduced on a trial basis in China back in 2015 and came into general effect on January 1, 2020.

This, then, is the Confucianism that Byung-Chul Han discusses as the main reason for the effectiveness of anti-coronavirus measures in East Asia. This view may apply in part to the PRC, in some respects to Singapore, and almost certainly to North Korea, although we do not know much about the actual situation there. It is a fact that the PRC used digital surveillance to monitor its population in the fight against the pandemic. Its digital control was certainly accompanied by the state authorities' paternalistic attitude towards the population, as expressed through intimidation and sometimes even open repression.

However, this is not the only reason for the success of anti-coronavirus measures in East Asia. The governments of different "soft" East Asian democracies, for example Taiwan, South Korea, and post-colonial Hong Kong, used no repressive measures in dealing with the pandemic, but were still extremely successful in limiting the spread. ${ }^{4}$ When explaining their success, the state representatives pointed out to quick reaction times in the early stages, transparent, continued and practically directed information campaigns about the spread of the disease, excellent health systems, and very good systems of organizing and coordinating the population,

\footnotetext{
${ }^{4}$ Especially Taiwan was seen throughout the world almost as a kind of "role model" for effective containment of the virus. This slightly changed during the third wave, i.e. by the mid-2021, when the disease's spread began to increase. However, this worsening of the situation was not connected to the patterns of people's behavior or any other social and ethical elements, but rather to the fact that - due to political reasons-Taiwan could not gain access to the vaccines soon enough.
} 
which also saw in the epidemic a common problem that could only be solved by society as a whole, and not exclusively by individuals.

This view of social phenomena is typical of the original Confucianism. In addition to the community's hierarchical and gerontocratic elements and possible pressures exerted on the individual, Confucianist ethics, on which most principles for ordering interpersonal relationships are still based today, also contains elements of original teachings that have nothing to do with oppression and totalitarianism. The relational ethic and understanding of the individual based on the complementary and mutually inseparable relationship between society and the people who are part of it has survived in East Asia to this day. In this framework, the human self is an inseparable part of an organic whole that every individual person forms together with the society to which it belongs and into which it grows. Therefore, we can refute the thesis of the immanently authoritarian organization of Sinic societies, as advocated, for example, in some classic works of European Orientalism (see, for example, Wittvogel), and offer instead a better grounded and more realistic image of Sinic Confucianism-based ethical and political systems.

For a better understanding of the differentiations described above, we will take a brief look below at the basic characteristics of such ethical systems that are based on discourses of the original Confucianism and can be grouped under the umbrella category of social or ethical relationism or relationality (guanxizhuyi, cf. Li, 2016).

\section{Relationism and Confucian "Role Ethics"}

The Confucian model of ethics that traditionally prevailed in the Sinic region is based on the primary role of the community. Its basic premise is that no one can survive (or even come into existence!) without others, that is, that society is the existential condition of the individual. In this context, we should emphasize from the outset the fact that the Sinic Confucian model of the relationship between the primary community and the secondary individual is neither a kind of collectivist, nor a kind of communitarian model of social interactions.

But if we start from the hypothesis that the efficiency of the measures against the coronavirus is linked to the traditional relational ethics prevailing in Sinic societies, we must also ask ourselves whether the internal organization of a society whose order is based on such an ethics is not also responsible for the low value attached to individual freedom, intimacy, and privacy. Indeed, as I have shown elsewhere (Rošker, 2021), a low worth placed on these values might facilitate social control of individuals and certain social groups. But due to the space limitations of the present paper, we will here primarily focus upon those structures of interpersonal relations that are instrumental for the establishment of social solidarity.

Traditional relational social orders belong to paradigms of interpersonal and political relations that are fundamentally different from individualist models in which the individual plays the key role. Indeed, in individualism, the individual's interests are also primary in an axiological sense, as opposed to those of the community, which are considered secondary. In the Sinic model, this relationship is complementary and based on the fundamental position of society, without which there would be no individuals at all.

Another fundamental difference between the Western individualist model and the Sinic relational system is that, in the individualist model, the individuals who make up the primary part of the relationship between society and the individual are considered equal, whereas Confucian and Sinic relationism are based on a clear distinction between individuals who are different.

Relational social orders are structured as webs of relationships that connect individuals who perceive themselves not as isolated and independent entities but as so-called relational selves. This means that the life and social roles of people in such systems are mutually interconnected and that their identities are to a large extent defined by their social relations. Within such a 
framework, the Self was always necessarily part of concrete situations; in Sinic culture, social positions were usually closely tied to Confucian traditions, in which conceptualizations of persons were usually centered on relationships. Of course, this also means that all of the individual's intentions, choices, successes, and failures must be understood in the context of their interactions with other people (Lai, 2018, p. 64). As Paul D'Ambrosio (2016, p. 720) points out, we can therefore view classical Confucianism as a form of moral interpretation of relationships as the fundamental components of human life and morality. In societies and cultures influenced by such a system of ethics, it is only within the framework of such relationality that people can experience what it means to be a human being endowed with morality, the values of humanity, and the analogical attitude towards one's life and one's social and natural environment.

Both Chinese and Sinological theorists usually interpret the Confucian model of the "five relations" described in the previous section of this paper as the foundations of interpersonal relations, ethical order, and mutual responsibility that are rationalized but also include human emotions (Li, 2016a, p. 1097). These basic relationships roughly define the way interpersonal interactions take place, as within the network each individual is assigned certain tasks and modes of behaviors. In Sinic societies, this model can often be seen as a nexus of basic interpersonal relationships within a civil society, as it encompasses familial relationships as well as relationships among friends and colleagues, and political and other social relationships. On the other hand, this also reflects the Confucian emphasis on the family as the basic cell of the state, as three of the five such model relationships have their origins in the family community. This basic organization of the five relationships is not only a description of our social relations, but also includes a set of concretely prescribed norms of behavior that order social interactions within such models, as each of the relationships included therein is tied to specific virtues (Wang, 2016, p. 194).

The central role in these morally defined interactions is occupied by the virtue of filial piety (xiao). This virtue, which is the constitutive element of children's love for their parents and grandparents, is one of the cardinal virtues of Confucian ethics. In concrete contexts, it usually means the fulfilment of a child's duty to their parents. In the context of Confucianism, filial piety is important primarily because the relationship between children and parents provides the earliest social environment in which a child learns to understand normativity within relationships and appropriate responses (Lai, 2016, p. 121). Thus, these virtues are initially formed within the family, that is, within boundaries that define an individual's duties and responsibilities. These are established based on different relationships between individual family members. Therefore, it is important for Confucian moral epistemology that family love is a priority and takes precedence over all other kinds of love. ${ }^{5}$ In a broader social context, this principle implies the priority of what is close over what is distant. Fan Ruiping's research (2010, p. xii) has shown that the Confucian emphasis on filial piety is closely related to the position that it is in the family that the foundations of virtuous living and morality are to be learned. The existential dependence of young children on their parents and the emotional dependence of the latter on the former are said to establish the human disposition to love. Therefore, for Confucians, love between parents and children is at the same time the foundation of the basic human virtue of humanity (ren). The latter, in turn, is central to any society of peace and prosperity, since it is based on mutual aid, trust, and solidarity.

We can thus assert that Confucianism is an ethical doctrine based on the moral interpretation of relationships as the fundamental constituents of human life and morality. Morality is then

\footnotetext{
${ }^{5}$ Here again we can observe one of the fundamental differences between Confucianism and Christianity that shapes the basic ideologies of Euro-American cultural thought, since before the Christian God all people are accorded equal love. For an excellent comparative analysis of these differences and their ethical implications, see Huang (2002, pp. 204-229).
} 
rooted in harmonious interactions between different people defined by different social roles. Li Zehou called this model of society and social ethics, which is not based on individualism but rather on social roles and relationships, "relationism" (guanxizhuyi). Many scholars believe that such an understanding of reality is more correct and realistic than social theories based on the ideas of the abstract individual, since in the real world there is no such thing as an individual in the sense of an isolated and "pure" Self, separate from all interpersonal intentions, feelings, and relationships, since no one can survive without others (Rosemont \& Ames, 2016, p. 9).

It is therefore not strange that numerous Chinese researchers are critically reexamining Western discourses and believe them to have a one-dimensional emphasis on individual autonomy and the idea of free choice. Such paradigms are in the end always based on the assumption that individuals can be separated and abstracted from social contexts, relationships, even from such elements of the human condition that are of actual vital importance for human life, such as, for example, the ability and the need for interpersonal relationships and mutual care (Fan, 2010, p. 13). Compared to such models, Confucian relationism is a model of relational being.

In relational social systems, individuals are not supposed to act as an independent moral agent, separate from their fellow people (Lai, 2018, p. 6). That is why judgements about the individual are never defined in relation to an idealized standard of an independent Self. In this kind of understanding of the Self, the actual relationships and environments define individual values, thoughts, motivations, behaviors, and actions in the first place. Moreover, relationships in this context are always marked by mutuality and reciprocal complementarity: "A good teacher and a good student can only emerge together, and your welfare and the welfare of your neighbor are coterminous and mutually entailing" (Rosemont \& Ames, 2016, p. 12). Even though relationism contains unequal positions - since the ruler is an authority to the subject, like the mother is to the daughter and so on - both parties who are involved in a specific relation are complementary and equal to one another, both in the metaphysical and the moral sense, since together they form a part of the social whole made up of those interpersonal relations.

This view of social composition is especially important in times of crisis, including those of the COVID-19 pandemic. Indeed, such times doubtlessly reinforce the need for cooperation that bridges the gap between the uniqueness of the individual on the one hand and their sociorelational Self on the other. It also poses a challenge to the artificially established dichotomies between the Self and the Other or between the specific and the general, the particular and the universal. This understanding is rooted in the paradigm of contrastive complementarity, as the unrepeatability of the individual can be measured not only by his or her individual achievements, but also by their social influence. And the latter, in turn, can be measured by an individual's position within their contextual environment and by their relations with other individuals (Lai, 2018, p. 88). From the perspective of ethics, such a relational network has several important implications, especially in comparison to frames that postulate a person's independent stability.

This kind of ethics does not derive from the concept of normative justice, but from a tendency towards social harmony (he), ${ }^{6}$ which appears in the relational network of interactions between individuals, whose individual identities are perceived as harmonies of different combinations of the unique, particular characteristics of each of them. The network of relationships is dynamic and diverse, since no one within it forms a fixed specific identity or entity. Everyone in it is the bearer of numerous roles, which are interwoven and which complement and perfect one another. Thus, I myself am, say, a mother, but also a daughter; I am a teacher, but also a researcher, which means that I learn from the work of others. I am also a consumer, a singer, a driver, a citizen, a worker, etc. Analogously, my relationships with

\footnotetext{
${ }^{6}$ Of course, this concept of social harmony should not be mistaken for the kind of ideologically misused concept of harmony that manifests itself in the patriotic propaganda of the leadership of China. For a more detailed description of such ideological misuses see Rošker (2012).
} 
people are multi-layered and changeable. Therefore, in the network of relationality, I am never simply a fixed and unchanging entity, defined by my role within the network.

As we have indicated before, Confucian relationism also contains a special type of virtue ethics, though not based on the concept of the isolated individual, but rather defined by relations, or relationships, which are in their essence emotional. ${ }^{7}$ Nevertheless, many other authors point out that it is rational and even necessary in visions of social systems to include, cultivate, and socialize emotions, since these are rooted in biological instincts that need to be directed towards mechanisms of mutual help (see Li, 2016a, p. 1097).

Another characteristic of relationism, which is important for crisis situations, such as the COVID-19 pandemic, is the factor of age-based inequality, which is certainly connected to the inequality of what is near and what is further away, of external and internal persons, ${ }^{8}$ and so on. Confucianism emphasizes familial relationships in which people are automatically unequal. That is why relationism contains both rational order and emotional identification within conditions that are always concrete, unrepeatable, and connected to sensations and feelings. In this context, specific obligations, responsibilities, and actions differ for every individual according to the concrete, changeable situation in which they are located.

As mentioned already, relationism begins in the relational individual self and is rooted in the family, developed outwards to the wider community and the natural environments in which people live. The ancient Confucian Mencius described this structure of society, explaining that "the basis of the world is the state, the basis of the state is the family, and the basis of the family is the individual" (Mengzi, s.d., Li Lou I: 5). ${ }^{9}$

The historical importance of the social system based on family clans is, of course, closely connected with the general importance of interpersonal relations. Thus, concrete relationships between different people formed a social network, which in time became a sociohistorical paradigm that was not limited to a simply regulated sequence of pairs, but assumed the socially and ethically important function of the basic element of systematized social interactions.

This discrepancy between the emphasis on the relationism on the one hand and individualism on the other can be seen as the basic difference between two types of ethics, which prevailed in Sinic and Western societies, respectively. The important foundation from which these differences emerge can be seen in the fact that the former is based on the combination of reason and feelings, while the latter is mostly connected to rational prescriptions. Besides, relationism is in no way a system that would wholly negate the individual or the individual's significance. However, compared to liberalism it does not perceive the individual as primary and superior to society.

\section{Conclusion}

Of course, relationism does not represent the perfect and best possible system of social organization, since it is rife with errors, dangers, and problems. Individualism, theoretically based on the equality of all people, allows — at least on a formal level — a general respect for all people and their points of view. Relationism, which is hierarchy-based at its very foundations,

\footnotetext{
${ }^{7}$ It is here worth pointing out that all three types of ethics, which are seen as the basic categories of this discipline, namely virtue ethics, deontological ethics, and utilitarian ethics, are categories that were established in the context of Western philosophy. Because transferring concepts and categories from one historical and cultural area to another is a problematic procedure (Silius, 2020, p. 258), tied to different culturally conditioned frames of reference, we have to take into account the fact that none of the above three categorizations are wholly suitable for defining or describing the basic nature of Confucian ethics, which at the same time certainly also belongs to the field of deontological ethics (cf. for example Lee, 2017, p. 94).

${ }^{8}$ The concepts of the "external" and the "internal" in this context refer to positions of people that are "inside" or "outside" certain social groups to which the subject, who is connected to these people, belongs.

9 天下之本在國, 國之本在家, 家之本在身。
} 
could never produce the kind of discourse ethics ${ }^{10}$ proposed by Habermas. The second important problem of relationism is evident in its tendency to harmonize individual situations based on pre-existing achievements and values, but also based on existing power relations. Even though relationism emphasizes flexibility and contextual dynamics, its hierarchical structure is inherently conservative in the sense that it hardly allows for innovations that might challenge the framework of existing ideas and social interactions. This danger is also related to the predominant role of emotions that connect people within the relational system and that often constitute an obstacle to the undisturbed functioning of laws, regulations, and sanctions. Thus, it could be said that relationism's greatest benefits are also its greatest risks. Moreover, due to globalization, traditional relationism is disintegrating in Sinic societies, and therefore there is a growing need in many East Asian populations to change the system and adapt it to the conditions of the contemporary world.

In the context of seeking durable solutions to crises such as the COVID-19 pandemic, it is nevertheless important to note that the basic framework of relationality and its associated values may well offer alternative possibilities or methods and ways of approaching a model of a more caring society, in the sense of a community based on an awareness and recognition of our responsibility and obligation to care for each other, as well as an awareness of our human vulnerability and our inherent interdependence.

\section{References}

CHUNQIU ZUO ZHUAN 春秋左傳 [The Spring and Autumn Annals], (s.d). In: D. Sturgeon (ed.): Chinese Text Project open-access library [online]. [Retrieved June 15, 2020] Available at: https://ctext.org/chun-qiu-zuo-zhuan.

D’AMBROSIO, P. (2016): Approaches to global ethics: Michael Sandel's justice and Li Zehou's harmony. In: Philosophy East and West, 66(3), pp. 720-738.

ESCOBAR, P. (2020a): Confucius is winning the Covid-19 war. In: Asia Times, April 13, 2020. [online] [Retrieved April 20, 2020] Available at: https://asiatimes.com/2020/04/confucius-iswinning-the-covid-19-war.

ESCOBAR, P. (2020b): COVID-19: Confucius is winning the coronavirus war. In: Consortium News, 26(139), pp. 1-24, April 16, 2020. [online] [Retrieved April 18, 2020] Available at: https://consortiumnews.com/2020/04/16/covid-19-confucius-is-winning-the-coronavirus-war/. FAN, R. (2010): Reconstructionist Confucianism: Rethinking morality after the West. Dordrecht: Springer.

HABERMAS, J. (1991): Erläuterungen zur Diskursethik. Frankfurt/Main: Suhrkamp.

HAN, B.-C. (2020a): La emergencia viral y el mundo de mañana. In: El País, March 22, 2020. [online] [Retrieved April 17, 2020] Available at: https://elpais.com/ideas/2020-03-21/laemergencia-viral-y-el-mundo-de-manana-byung-chul-han-el-filosofo-surcoreano-que-piensadesde-berlin.html.

HAN, B.-C. (2020b): COVID-19 has reduced us to a 'Society of survival'. In: C. Sigüenza \& E. Rebollo (interviewers): Euractive, May 24, 2020, pp. 1-4 [online] [Retrieved June 8, 2020] Available at: https://www.euractiv.com/section/global-europe/interview/byung-chul-hancovid-19-has-reduced-us-to-a-society-of-survival.

\footnotetext{
${ }^{10}$ Discourse ethics is a theory whose central criterion is discourse (cf. Habermas, 1991). This means that the correctness or rationality of the ethical assumptions (prescriptive claims) it makes is tested by means of discourse, which is formed based on rational arguments. Discourse ethics contains a cognitive meta-ethics, since the community of all participants in the discourse can (ideally) determine what is right. Discourse ethics differs from individualistic ethics in that its results are obtained through the process of intersubjective interactions. Therefore, it is useful for solving problems that go beyond the sphere of the individual, such as problems that arise in politics and the global economy.
} 
HUANG, Y. 黄勇 (2002): Rujia ren'ai guan yu qianqiu lunli: jian lun jidu jiao dui rujiade piping 儒家仁爱观与全球伦理: 兼论基督教对儒家的批评. In: Sixiang yu wenhua, 2002(2), pp. 204-229.

LAI, K. (2018): Global thinking. Karyn Lai's thoughts on new waves in Anglo-Chinese philosophy. In: The Philosopher's Magazine, 2018(1), pp. 64-69.

LEE, M-H. (2017): Confucianism: Its roots and global significance. Honolulu: University of Hawai'i Press.

LI, Z. 李澤厚 (2016): Renleixue lishi bentilun 人類學歷史本體論 [Anthropo-historical ontology]. Qingdao: Qingdao chuban she.

LI, Z. (2016a): A response to Michael Sandel and other matters, trans. P. D'Ambrosio \& R. A. Carleo. In: Philosophy East and West, 66(4), pp. 1068-1147.

LUNYU [The Analects], (s.d.) In: D. Sturgeon (ed.): Chinese Text Project open-access library [online]. [Retrieved June 7, 2020] Available at: https://ctext.org/analects.

MENGZI (s.d.): Mengzi 孟子 [Mencius]. In: D. Sturgeon (ed.): Chinese Text Project openaccess library [online]. [Retrieved June 15, 2020] Available at: https://ctext.org/mengzi.

OVIEDO, A. (2020): Cooperation and solidarity: Between Slavoj Žižek and Byung Chul Han. In: Latin America in Movement, April 2, 2020, pp. 1-8. [online] [Retrieved June 8, 2020] Available at: https://www.alainet.org/en/articulo/205649.

ROSEMONT, H. Jr. \& AMES, R. T. (2016): Confucian Role-Ethics: A moral vision for the 21st Century? Taipei: National Taiwan University Press.

ROŠKER, J. S. (2012): Cultural conditionality of comprehension: The perception of autonomy in China. In: Cao Q., Tian H. \& P. Chilton (eds.): Reinventing identities: The poetic of language use in contemporary China. Tianjin: Nankai daxue chuban she, pp. 26-42.

ROŠKER, J. S. (2021): Increase in racism during the COVID-19 pandemic and the ontology of race: intercultural comparison of European and Chinese traditions. In: Economic and Business Review (forthcoming).

SERNELJ, T. (2020): Different approaches to Chinese aesthetics: Fang Dongmei and Xu Fuguan. In: Asian Studies, 8(3), pp. 161-182, [online] [Retrieved June 8, 2020] Available at: https://revije.ff.uni-lj.si/as/article/view/9200/9104

SILIUS, V. (2020): Diversifying academic philosophy: The Post-Comparative turn and transculturalism. In: Asian Studies, 8(2), pp. 257-280, [online] [Retrieved June 9, 2020] Available at: https://revije.ff.uni-lj.si/as/article/view/8717/8966

WANG, Q. (2016): The relational self and the Confucian familial ethics. In: Asian Philosophy, 26(3), pp. 193-205.

WITTFOGEL, K. A. (1957): Oriental despotism: A comparative study of total power. New Haven: Yale University Press.

XUNZI (s.d.): Xunzi 荀子. In: D. Sturgeon (ed.): Chinese text project open-access library [online]. [Retrieved June 15, 2020] Available at: https://ctext.org/xunzi. 